\title{
PENGKAYAAN Artemia sp. MENGGUNAKAN VITAMIN A DENGAN DOSIS BERBEDA UNTUK PERTUMBUHAN BENIH IKAN PATIN (Pangasius sp.)
}

\section{ENRICHMENT OF Artemia sp. USING DIFFERENT DOSES OF VITAMIN A FOR THE GRWOTH OF CATFISH SEEDS (Pangasius sp.)}

\author{
Laura Marni Lestari $^{\left.1^{*}\right)}$, Ediyanto $^{1}$, Firsty Rahmatia ${ }^{1}$ \\ ${ }^{1}$ Fakultas Perikanan dan Ilmu Kelautan Universitas Satya Negara Indonesia \\ Korespondensi : Lauramarni44@gmail.com
}

\begin{abstract}
ABSTRAK
Ikan patin (Pangasius sp.) merupakan salah satu jenis ikan air tawar asli indonesia yang terbesar di sebagian wilayah Sumatera dan Kalimantan. Ikan Patin termasuk komoditas yang memiliki prospek cerah untuk dibudidayakan. Oleh sebab itu dibutuhkan berbagai langka alternatif untuk mempercepat pertumbuhan, salah satunya adalah pengkayaan nutrisi Artemia sp. dengan penambahan vitamin A. Kelebihan Artemia sebagai pakan alami adalah memiliki kandungan pigmen (canthaxanthin), protein, vitamin dan beberapa asam lemak penting untuk pertumbuhan dan kelangsungan hidup ikan. Vitamin A berperan penting dalam regulasi genetik, pertumbuhan serta perkembangan normal, dan kekebalan tubuh. Tujuan dari penelitian ini adalah: mengetahui pengaruh pemberian pakan Artemia sp. yang telah dilakukan pengkayaan terhadap pertumbuhan benih ikan Patin dan mengetahui dosis vitamin A terbaik terhadap pertumbuhan benih ikan Patin. Hasil penelitian diperoleh Laju pertumbuhan harian benih ikan Patin rata-rata 1,115 - 1,192\%/hari. Laju bobot harian benih ikan Patin rata-rata $0,006-0,007 \%$ /hari. Pertumbuhan panjang mutlak benih ikan Patin rata-rata 2,682 - 2,917 \%/hari. Pertumbuhan bobot mutlak rata-rata 0,272 - 0,287 $\% /$ hari. Tingkat kelangsungan hidup benih ikan Patin rata-rata 58,25 - 80,25\%. Tingkat konversi pakan benih ikan Patin rata-rata 0,389 - 0,409\%. Abnormalitas benih ikan Patin $\begin{array}{lllll}\text { rata-rata } & 1,00 & - & 24,00 & \% \text {. }\end{array}$
\end{abstract} KATA KUNCI : Benih Ikan Patin, Artemia, Vitamin A

\begin{abstract}
Jambal catfish (Pangasius sp.) is one of the largest native Indonesian freshwater fish species in parts of Sumatra and Kalimantan. Patin fish is a commodity that has bright prospects for cultivation. In line with the high market demand for Patin fish, fulfilling it of course can be cultivated either traditionally, semi-intensively, intensively, or superintensively to increase the production of Patin fish. Therefore
\end{abstract}


it takes a variety of rare alternatives to accelerate growth, one of which is nutritional enrichment of Artemia sp. with the addition of vitamin A. The advantages of Artemia as natural food are that it contains pigments (canthaxanthin), protein, vitamins and several fatty acids essential for the growth and survival of fish. Vitamin A plays an important role in genetic regulation, normal growth and development, and immunity. The objectives of this study were: to determine the effect of feeding Artemia sp. Enrichment has been carried out on the growth of catfish seeds and knows the best dose of vitamin A on the growth of catfish seeds. The results showed that the daily growth rate of catfish seeds was $1.115-1.192 \%$ / day. The daily weight rate of Patin fish seeds averaged $0.006-0.007 \% /$ day. The growth of the absolute length of the catfish fry was 2,682 - 2,917\% / day on average. The growth in absolute weight averaged $0.272-0.287 \%$ / day. The survival rate of the catfish seeds was $58.25-80.25 \%$. The conversion rate of the catfish seed feed was $0.389-0.409 \%$. The abnormalities of the catfish seeds were $1.00-24.00 \%$ in average. KEYWORD : Pangasius seed, Artemia, Vitamin A

\section{PENDAHULUAN}

Ikan Patin (Pangasius sp.) merupakan salah satu jenis ikan air tawar asli indonesia yang terbesar di sebagian wilaya Sumatera dan Kalimantan (Djarijah, 2001). Ikan Patin termasuk komoditas yang memiliki prospek cerah untuk dibudidayakan. Ikan Patin berpotensi besar sebagai komoditas ekspor karena memiliki daging berwarna putih yang disukai oleh konsumen diluar negeri seperti Amerika Serikat dan Eropa (Hardinata, 2009). Pada tahun 2018, KKP menargetkan produksi patin sebesar 604.587 ton per tahun dengan preferensi produk yang di konsumsi dalam bentuk segar sebesar $76 \%$ dan ikan awet sebesar $15 \%$, target ikan Patin meningkat $38,31 \%$ dari tahun sebelumnya (Kemenkes, 2018).

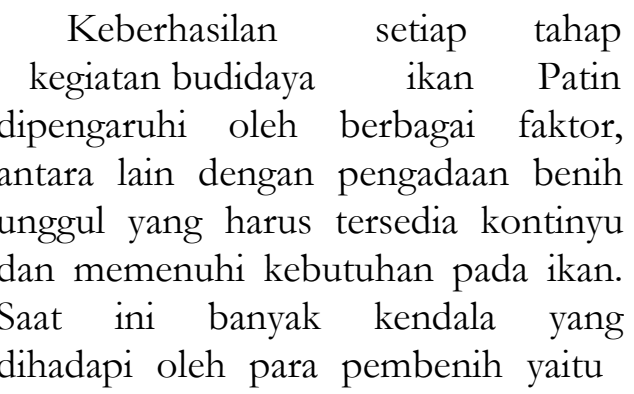

pada pertumbuhan yang lambat dan kematian dengan tingkat kelangsungan hidup 76,17 $\pm 12,78 \%$ (Setiawan et al., 2013). Oleh sebab itu dibutuhkan berbagai langka alternatif untuk mempercepat pertumbuhan, salah satunya adalah pengkayaan nutrisi Artemia sp. dengan penambahan vitamin $A$.

Kelebihan Artemia sebagai
pakan alami adalah memiliki
kandungan pigmen (canthaxanthin),
protein, vitamin, dan beberapa asam
lemak penting untuk pertumbuhan
dan kelangsungan hidup ikan
(Hafezieh et al., 2009). Menurut
penelitian Setiawan et al., 2013,
menyatakan bahwa benih ikan Patin
yang diberi pakan Artemia
memberikan pertumbuhan panjang
mutlak berkisaran 1,48 0,08
$\% /$ hari, bobot mutlak $14,80 \pm 3,10$
$\% /$ hari (mg), dan tingkat
kelangsungan hidup $60,67 \pm 8,13 \%$.
Menurut penelitian Hardiman et al.
(2017) mengatakan bahwa
pemberian pengkayaan Artemia sp.
dengan dosis vitamin A yang bereda
memberi pengaruh terhadap


pertumbuhan bobot dan kelangsungan hidup ikan Gabus. Menurut penelitian (Ernawati et al., 2019) larva ikan Nila diberi pakan Artemia yang diperkaya menggunakan karatenoid sebanyak $10,00 \mathrm{mg} / \mathrm{L}$ efektif dalam meningkatkan laju pertumbuhan, kelangsungan hidup dan ketahanan stres. Vitamin A berperan penting dalam regulasi genetik, pertumbuhan serta perkembangan normal, dan kekebalan tubuh. Kebutuhan ikan akan vitamin dipengaruhi oleh ukuran, laju pertumbuhan, stres lingkungan dan hubungan antar nutrien (Afrianto et al., 2005). Oleh karena itu penelitian tentang pengkayaan Artemia sp. menggunakan vitamin A dengan dosis berbeda untuk pertumbuhan benih ikan Patin (Pangasius sp.) ini perlu dilakukan.

\section{METODE PENELITIAN}

Bahan penelitian terdiri atas hewan uji, pakan uji dan bahan pendukung penelitian. Hewan uji yang digunakan adalah benih Ikan Patin, pakan uji yang digunakan adalah Artemia yang diperkaya menggunkan vitamin A. Alat-alat yang digunakan meliputi akuarium dengan ukuran $25 \times 20 \times 20 \mathrm{~cm}$ sebanyak 28 buah, kamera digital, termometer, $\mathrm{pH}$ meter, penggaris, timbangan digital, instalasi aerasi, selang sipon, botol air mineral 1,5 L, refraktometer, heater dan alat tulis. Data yang diperoleh diuji sidik ragam (ANOVA). Apabila hasil yang diperoleh signifikan maka dilanjutkan dengan uji Tukey untuk mengetahui perbedaan antara perlakauan dengan menggunakan software SPSS versi 16. Selanjutnya data akan disajikan dalam bentuk tabel dan grafik.

\section{Prosedur Penelitian}

Persiapan wadah uji akuarium berukuran $25 \times 20 \times 20 \mathrm{~cm}$ sebanyak 28 buah yang diisi air dengan volume 4 L, akuarium yang akan digunakan disterilisasikan terlebih dahulu. Ikan uji yang digunaakan benih Ikan Patin yang didapat dari petani ikan di Alamayang, Kota Pekanbaru, Riau. Ikan yang dipilih normal dan sehat dengan ukuran panjang rata-rata $0,1-$ $0,5 \mathrm{~mm}$ dengan bobot rata-rata 0,001- 0,003 gram, masing-masing akuarium diisi air sebanyak $4 \mathrm{~L}$ dengan kepadatan 15 ekor/L.

Pengkultur Artemia dilakukan menggunakan wadah akua botol 1,5 $\mathrm{L}$ yang telah di lubangin bagian bawahnya, kemudian penambahan selang aerasi. Penetasan kista Artemia dilakukan sebanyak 1 gram/L. Wadah penetasan diisi air tawar sebanyak 1 L kemudian di tambahkan garam 30 gram/L, penambahan garam dilakukan untuk mendapatkan salinitas $30 \mathrm{ppt}$. Setelah kista Artemia dimasukan ke dalam wadah penetasan dan diberi aerasi kencang selama 24 jam sehingga kista Artemia dapat teraduk dengan baik. Setelah 24 jam kista Artemia baru menetas dan dilakukan pemanenan. Pemanenan dilakukan dengan menggunakan plankto net/seser halus, Artemia yang telah di panen kemudian dilakukan pengkayaan. Pengkayaan dilakukan menggunakan akua botol dan penambahan vitamin A sesuai dosis perlakuan selama 4 jam. Setelah melakukan pengkayaan Artemia dipanen kemudian dibilas dengan air tawar. Pengukuran laju pertumbuhan yang diukur meliputi panjang dan bobot benih ikan Patin setiap 10 hari sekali 


\section{Rancangan Percobaan}

Penelitian ini menggunakan Rancangan Acak Lengkap (RAL) dengan 7 perlakuan dan 4 ulangan perlakuan yang digunakan adalah sebagai berikut:

Perlakuan A : Artemia tanpa pengkayaan (Kontrol)

Perlakuan B : Artemia + vitamin A $20 \mathrm{mg} / \mathrm{L}$

Perlakuan C : Artemia + vitamin A $40 \mathrm{mg} / \mathrm{L}$

Perlakuan D : Artemia + vitamin A $60 \mathrm{mg} / \mathrm{L}$

Perlakuan E : Artemia + vitamin A $80 \mathrm{mg} / \mathrm{L}$

Perlakuan F : Artemia + vitamin A $100 \mathrm{mg} / \mathrm{L}$

Perlakuan G : Artemia + vitamin A $120 \mathrm{mg} / \mathrm{L}$

\section{Parameter Uji}

1. Laju Pertumbuhan Harian

Pengukuran laju pertumbuhan bobot dan panjang harian dilakukan setiap 10 hari sekali. Laju Pertumbuhan panjang harian dihitung dengan menggunakan rumus (Widyiantara, 2009) sebagai berikut:

$$
\mathrm{Ph}=(\operatorname{In~Lt}-\text { In L0) / t X 100\% }
$$

Keterangan :

$\mathrm{Ph} \quad$ : Laju Pertumbuhan panjang harian $(\%)$

Lt : Panjang rata-rata akhir $(\mathrm{cm})$ :

L0 Panjang rata-rata awal $(\mathrm{cm})$ :

$\mathrm{t}$ Lama pemeliharan (hari) Laju pertumbuhan bobot

harian dapat dihitung berdasarkan rumus (Verdegem dan Eding, 2010)

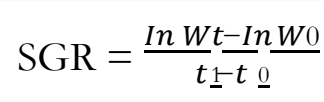

Keterangan :
SGR : Laju pertumbuhan bobot harian $(\%)$

Wt : Bobot rata-rata ikan di akhir pemeliharaan (ekor)

W0 : Bobot rata-rata ikan di awal pemeliharaan (ekor)

$\mathrm{t} \quad$ : Lama waktu pemeliharaan

(hari)

2. Pertumbuhan Mutlak

Pertumbuhan mutlak dihitung menggunakan rumus Effendie (2002), sebagai berikut :

Pertumbuhan panjang mutlak

$$
\mathrm{L}=\mathrm{Lt}-\mathrm{Lo}
$$

Keterangan :

L : Pertumbuhan panjang mutlak ikan yang dipelihara $(\mathrm{cm})$

Lt : Panjang ikan pada akhir pemeliharaan $(\mathrm{cm})$

Lo : Panjang ikan pada awal pemeliharaan $(\mathrm{cm})$

Pertumbuhan bobot mutlak

$$
\mathrm{W}=\mathrm{Wt}-\mathrm{Wo}_{\mathrm{O}}
$$

Keterangan :

W : Pertumbuhan bobot mutlak ikan yang dipelihara (gram)

Wt : Bobot ikan pada akhir pemeliharaan (gram)

W0 : Bobot ikan uji pada awal pemeliharaan (gram)

3 Tingkat Kelangsungan Hidup Secara umum kelangsungan hidup dapat dihitung dengan rumus Castel dan Tiews, 1980 dalam Saputra, 2010).

$$
\mathrm{SR}=\frac{N t}{N o} \times 100
$$


Keterangan:

SR : Persentase kelangsungan

hidup ikan $(\%)$

$\mathrm{Nt}$ : Jumlah ikan pada akhir

penelitian (ekor)

No : Jumlah ikan pada awal

penelitian (ekor)

4 Rasio Konversi Pakan (FCR)

Menurut Effendie (1997), rasio

konversi pakan atau food convertion ratio (FCR) dapat dihitung dengan rumus sebagai berikut:

$$
\mathrm{FCR}=\frac{F}{(W t+D)-W o}
$$

Keterangan:

FCR : Feed Conversion Ratio

F : Jumlah pakan yang

dikonsumsi selama penelitian (g)

Wt : Biomassa akhir (g)

D : Bobot ikan mati

Wo (gram) : Biomassa awal

5 A(g)ormalitas Ikan

Untuk

menentukuan

abnormalitas larva dihitung dengan menggunakan persamaan (Effendie, 1979), sebagai berikut:

$100 \%$

\section{HASIL DAN PEMBAHASAN}

\section{a. Laju Pertumbuhan Harian}

Pertumbuhan benih ikan Patin dapat dilihat dari laju pertumbuhan panjang harian dan laju pertumbuhan bobot harian. Hasil pengamatan akhir bobot rata-rata harian selama 40 hari berdasarkan penelitian pemberian Artemia sp. yang diperkaya menggunakan vitamin A dengan dosis berbeda dapat dilihat pada Tabel 1 .
Tabel 1. Hasil Analisis Pertumbuhan Benih Ikan Patin

\begin{tabular}{|c|c|c|c|}
\hline $\mathrm{No}$ & $\begin{array}{l}\text { Perlak } \\
\text { uan }\end{array}$ & $\begin{array}{l}\text { Laju } \\
\text { Pertumbu } \\
\text { han } \\
\text { Panjang } \\
\text { Harian } \\
(\%)\end{array}$ & $\begin{array}{l}\text { Laju } \\
\text { Pertumbu } \\
\text { han Bobot } \\
\text { Harian } \\
(\%)\end{array}$ \\
\hline 1. & $\bar{A}$ & $\begin{array}{l}1,115 \\
0,023^{\mathrm{a}}\end{array}$ & $\begin{array}{l}0,006 \\
0,000^{\mathrm{a}}\end{array}$ \\
\hline 2. & B & $\begin{array}{l}1,177 \\
0,034^{\mathrm{a}}\end{array} \quad \pm$ & $\begin{array}{l}0,007 \\
0,000^{\mathrm{a}}\end{array}$ \\
\hline 3. & $\mathrm{C}$ & $\begin{array}{l}1,192 \\
0,025^{a}\end{array}$ & $\begin{array}{l}0,007 \\
0,000^{a}\end{array}$ \\
\hline 4. & D & $\begin{array}{l}1,160 \pm \\
0,041^{\mathrm{a}}\end{array}$ & $\begin{array}{l}0,007 \\
0,000^{\mathrm{a}}\end{array}$ \\
\hline 5. & $\mathrm{E}$ & $\begin{array}{l}1,175 \\
0,063^{\mathrm{a}}\end{array} \quad \pm$ & $\begin{array}{l}0,007 \\
0,000^{a}\end{array}$ \\
\hline 6. & $\mathrm{~F}$ & $\begin{array}{l}1,132 \\
0,035^{\mathrm{a}}\end{array}$ & $\begin{array}{l}0,006 \\
0,000^{\mathrm{a}}\end{array}$ \\
\hline 7. & G & $\begin{array}{l}1,155 \\
0,051^{\mathrm{a}}\end{array} \quad \pm$ & $\begin{array}{l}0,006 \\
0,000^{\mathrm{a}}\end{array}$ \\
\hline
\end{tabular}

Keterangan:

Nilai yang diikuti huruf kecil yang sama tidak berbeda nyata berdasarkan uji jarak berganda Tukey pada taraf 95\%.

Uji statistik menunjukkan bahwa pemberian Artemia yang diperkaya menggunakan vitamin A dengan dosis berbeda memberi pengaruh yang tidak berbeda nyata $(p>0,05)$ terhadap laju pertumbuhan panjang harian benih ikan Patin. Rata-rata laju pertumbuhan panjang harian berkisar antara 1,115 - 1,192 $\% /$ hari. Hasil uji statistik laju pertumbuhan harian.

Hal ini diduga meningkatnya pertumbuhan panjang harian karena dipengaruhi dosis pengkayaan Artemia dengan vitamin A memberi efek baik bagi pertumbuhan panjang benih ikan Patin, dimana vitamin A memiliki bahan aktif retinol yang berfungsi sebagai pertumbuhan dan kekebalan tubuh. Vitamin A dalam tubuh dibentuk untuk perkembangan 
tulang, Kodłurategatel. vitamin A akan pertumbuhan terhambat dan ben tulang tidak normal menyebabkan nafsu makan mákinto rendah. Sesuai dengan pernyataan Effendie (1997), pertumbu dipengaruhi oleh faktor internal dan eksternal, faktor internal sebagian besar tergantung pada kondisi tubuh ikan tersebut, misalnya kemamp ikan dalam memanfaatkan sisa enđrgi dan protein setelah metaboli e untuk pertumbuhannya, falotor eksternal seperti faktor lingkun $\mathrm{n}$ dan pakan sangat berpengaruh pa pertumbuhan ikan. Faktor kedua tersebut akan berpengaruh untuk menyeimbangkan keadaan tubuh ikan selama dalam masa pemeliharaan.

Pemberian Artemia yang diperkaya menggunakan vitamin A dengan dosis berbeda memberikan pengaruh yang tidak berbeda nyata $(p>0,05)$ terhadap laju pertumbuhan bobot harian benih ikan Patin. Hasil uji statistik laju pertumbuhan bobot harian dapat dilihat pada Tabel 1. Laju pertumbuhan bobot harian benih ikan Patin mengalami kenaikan selama penelitian, hal ini diduga bahwa kandungan nutrisi pada pakan dapat diubah menjadi energi oleh ikan Patin. Sesuai dengan pernyataan Lovell (1984), kebutuhan ikan terhadap vitamin A untuk mendapatkan pertumbuhan bobot yang optimum sangat tergantung pada species, umur, ukuran ikan, laju pertumbuhan, lingkungan dan fungsi metabolisme tubuh bahkan dapat sebagai faktor pertumbuhan bobot.

b. Pertumbuhan Panjang Mutlak Berdasarkan hasil uji pertumbuhan panjang mutlak benih ikan Patin berdasarkan hasil penelitian pemberian pakan Artemia menyebabkang telah diperkaya menggunakan vitkmin A dengan dosis berbeda dapat dilihat pada Tabel 2 .

el 2. Hasil Analisis Pertumbuhan Panjang Mutlak Ikan Patin

\begin{tabular}{lcl}
\hline Perlakuan & $\begin{array}{l}\text { Panjang Mutlak } \\
(\%)\end{array}$ \\
\hline & A & $2,682 \pm 0,049^{\mathrm{a}}$ \\
& $\mathrm{B}$ & $2,850 \pm 0,108^{\mathrm{a}}$ \\
3. & $\mathrm{C}$ & $2,917 \pm 0,076^{\mathrm{a}}$ \\
& $\mathrm{D}$ & $2,802 \pm 0,111^{\mathrm{a}}$ \\
5. & $\mathrm{E}$ & $2,855 \pm 0,218^{\mathrm{a}}$ \\
& $\mathrm{F}$ & $2,272 \pm 0,107^{\mathrm{a}}$ \\
7. & $\mathrm{G}$ & $2,827 \pm 0,166^{\mathrm{a}}$ \\
\hline
\end{tabular}

keterangan:

Nilai yang diikuti huruf kecil yang sama ada pengaruh berdasarkan uji jarak berganda Tukey pada taraf 95\%.

Hasil uji statistik menunjukkan bahwa pemberian pakan Artemia yang diperkaya menggunakan vitamin A dengan dosis berbeda memberikan pengaruh yang tidak berbeda nyata $(p>0,05)$ terhadap pertumbuhan panjang mutlak benih ikan Patin. Rata-rata pertumbuhan panjang mutlak benih ikan Patin berkisar antara 2,682 $2,917 \%$ /hari. Hal ini diduga karena ikan setiap perlakuan memiliki kemampuan dalam merespon dan memanfaatkan pakan untuk pertumbuhan. Sesuai dengan hasil pernyataan Hariati (1989), bahwa semakin tinggi dosis vitamin A yang diberikan maka semakin tinggi metabolisme dalam tubuh ikan sehingga konsumsi pakan yang diberikan sesuai makan akan meningkatkan pertumbuhan panjang. Sesuai dengan pernyataan Bunasir et al. (2002) yang menyatakan bahwa pertumbuhan ikan dipengaruhi oleh kemampuan dalam merespon dan memanfaatkan kuantintas pakan yang diberikan. Pada perlakuan A 
(kontrol) dapat dilihat rata-rata pertumbuhan panjang mutlak benih ikan Patin berkisaran 2,682 \pm 0,049 $\% /$ hari, Sesuai dengan penelitian Setiawan et al., 2013, pada perlakuan kontrol pada pertumbuhan panjang mutlak benih ikan Patin diperoleh hasil 1,48 $\pm 0,08 \% /$ hari rata-rata pada perlakuan kontrol memiliki hasil yang tidak berbeda jauh.

c. Pertumbuhan Bobot Mutlak Berdasarkan hasil uji lanjut pertumbuhan bobot mutlak benih ikan Patin berdasarkan hasil penelitian pemberian pakan Artemia yang telah diperkaya menggunakan vitamin A dengan dosis berbeda dapat dilihat pada Tabel 3 .

Tabel 3. Hasil Analisis Pertumbuhan

Bobot Mutlak Benih Ikan Patin

\begin{tabular}{ll}
\hline No Perlakuan & $\begin{array}{l}\text { Bobot Mutlak } \\
(\%)\end{array}$ \\
\hline 1. A $\quad$ A & $0,272 \pm 0,025^{\mathrm{a}}$ \\
2. B 3. C & $0,280 \pm 0,000^{\mathrm{a}}$ \\
& $0,285 \pm 0,005^{\mathrm{a}}$ \\
4. D 5. E & $0,277 \pm 0,005^{\mathrm{a}}$ \\
& $0,272 \pm 0,005^{\mathrm{a}}$ \\
6. F 7. G & $0,277 \pm 0,015^{\mathrm{a}}$ \\
& $0,277 \pm 0,012^{\mathrm{a}}$ \\
\hline
\end{tabular}

Keterangan:

Nilai yang diikuti huruf kecil yang sama tidak berbeda nyata berdasarkan uji jarak berganda Tukey pada taraf 95\%.

Berdasarkan hasil analisis uji statistik menujukkan bahwa pemberian Artemia yang diperkaya menggunakan vitamin A dengan dosis berbeda memberikan pengaruh yang tidak berbeda nyata $(p>0,05)$ terhadap pertumbuhan bobot mutlak benih ikan Patin. Rata-rata pertumbuhan bobot mutlak berkisar antara 0,272 - 0,285 \%/hari. Hal diduga kemampuan ikan uji dalam mengkonsumsi Artemia yang telah diperkaya menggunakan vitamin A mampu dicerna dengan baik sehingga pertumbuhan optimum. Pertumbuhan bobot benih ikan Patin tidak hanya dipengaruhi oleh nitrisi ikan. Sesuai dengan hasil pernyataan Effendie (1997) dalam Agus et al. (2010) menyatakan bahwa pertumbuhan ikan dipengaruhi oleh beberapa faktor yaitu jumlah dan ukuran pakan. Pada perlakuan A (kontrol) dapat dilihat rata-rata pertumbuhan bobot mutlak benih ikan Patin berkisaran 0,272 $\pm 0,025$ $\% /$ hari, Sesuai dengan penelitian Mia et al., 2013, pada perlakuan kontrol pada pertumbuhan bobot mutlak benih ikan Patin diperoleh hasil $14,80 \pm 3,10 \% /$ hari $(\mathrm{mg})$ rata-rata pada perlakuan kontrol memiliki hasil yang tidak berbeda jauh.

4. Tingkat Kelangsungan Hidup (Survival Rate)

Berdasarkan hasil uji lanjut tingat kelangsungan hidup benih ikan Patin berdasarkan hasil penelitian pemberian pakan Artemia yang telah diperkaya menggunakan vitamin A dengan dosis berbeda dapat dilihat pada Tabel 4.

Tabel 4. Hasil Analisis Tingkat Kelangsungan Hidup

\begin{tabular}{lcl}
\hline No & Perlakuan & $\begin{array}{l}\text { Tingkat } \\
\text { Kelangsungan } \\
\text { Hidup } \\
(\%)\end{array}$ \\
\hline 1. & A & $61,500 \pm 4,358^{\mathrm{a}}$ \\
2. & $\mathrm{B}$ & $63,500 \pm 4,358^{\mathrm{a}}$ \\
3. & $\mathrm{C}$ & $72,000 \pm 8,869^{\mathrm{a}}$ \\
4. D & 5. E & $67,000 \pm 4,320^{\mathrm{a}}$ \\
& & $63,000 \pm 3,915^{\mathrm{a}}$ \\
6. F 7. G & $68,750 \pm 6,946^{\mathrm{a}}$ \\
& & $66,750 \pm 5,377^{\mathrm{a}}$ \\
\hline
\end{tabular}

Keterangan:

Nilai yang diikuti huruf kecil yang sama tidak berbeda nyata berdasarkan uji jarak berganda Tukey pada taraf $95 \%$. 
Hasil uji statistik menunjukkan bahwa perlakuan pemberian pakan Artemia yang diperkaya menggunakan vitamin A dengan dosis berbeda memberikan pengaruh yang tidak berbeda nyata $(p>0,05)$ terhadap kelangsungan hidup benih ikan Patin. Rata-rata tingkat kelangsungan hidup berkisar antara 61,500 - 72,00 \%. Hal ini diduga semakin tinggi dosis yang digunakan semakin bagus untuk tingkat kelangsungan hidup benih ikan Patin karena retinol sebagai bahan aktif berfungsi dengan baik dalam tubuh ikan dimana kekurangan vitamin A dapat menurunkan respon antibodi. Sesuai dengan hasil penelitian Dedi et al. (1995), vitamin A mempunyai peranan dalam tubuh ikan dapat meningkatkan metabolisme dan mencegah terjadinya kelainan pada tubuh dan dapat mengurangi stres dan juga dapat mencegah terjadinya serangan penyakit. Sesuai dengan penelitian Yurisman dan Heltonika (2010), tingkat kelangsungan hidup suatu organisme dapat dipengaruh oleh faktor biotik dan abiotik. Faktor biotik yaitu kepatan populasi, umur dan kemampuan organisme dengan lingkungan, sedangkan faktor abiotik antara lain seperti suhu, oksigen terlarut, $\mathrm{pH}$ dan amoniak. Selain itu tingkat kelangsungan hidup juga dapat dipengaruhi dari faktor internal dan eksternal. Salah satunya cara untuk menciptakan lingkungan yang ideal adalah dengan melakukan pergantian air. Menggingat tidak semua benih mengalami kematian, maka dapat dipastikan bahwa daya toleransi setiap benih dalam wadah berbeda-beda, baik terhadap pakan maupun kondisi lingkungan seperti kualitas air yang masi dalam kisaran layak bagi kehidupan benih.
Pada perlakuan A (kontrol) dapat dilihat rata-rata tingkat kelangsungan hidup benih ikan Patin berkisaran 61,500 \pm 4,358 \%, Sesuai dengan penelitian Mia et al., 2013, pada perlakuan kontrol pada tingkat kelangsungan hidup benih ikan Patin diperoleh hasil $60,67 \pm 8,13 \%$ ratarata tingkat kelangsungan hidup pada benih ikan Patin tidak berbeda jauh.

5. Tingkat Konversi Pakan (FCR)

Berdasarkan hasil uji lanjut

FCR benih ikan Patin berdasarkan hasil penelitian pemberian pakan Artemia yang telah diperkaya menggunakan vitamin A dengan dosis berbeda dapat dilihat pada Tabel 5.

Tabel 5. Hasil Analisis Rasio Koversi Pakan (FCR)

\begin{tabular}{lcc}
\hline No & Perlakuan & FCR $(\%)$ \\
\hline 1. & A & $0,407 \pm 0,038^{\mathrm{a}}$ \\
2. & $\mathrm{B}$ & $0,391 \pm 0,005^{\mathrm{a}}$ \\
3. & $\mathrm{C}$ & $0,389 \pm 0,008^{\mathrm{a}}$ \\
4. & $\mathrm{D}$ & $0,399 \pm 0,008^{\mathrm{a}}$ \\
5. & $\mathrm{E}$ & $0,400 \pm 0,004^{\mathrm{a}}$ \\
6. & $\mathrm{F}$ & $0,405 \pm 0,021^{\mathrm{a}}$ \\
7. & $\mathrm{G}$ & $0,398 \pm 0,020^{\mathrm{a}}$ \\
\hline
\end{tabular}

Keterangan:

Nilai yang diikuti huruf kecil yang sama tidak berbeda nyata berdasarkan uji jarak berganda Tukey pada taraf 95\%.

Hasil uji statistik menunjukkan bahwa pemberian pakan Artemia yang diperkaya menggunakan vitamin A dengan dosis berbeda memberikan pengaruh yang tidak berbeda nyata $(\mathrm{P}>0,05)$ terhadap FCR. Rata-rata FCR berkisar antara 0,391 - 0,407\%/hari. Hal ini diduga bahwa vitamin A tidak berpengaruh terhadap konsumsi pakan ikan, tetapi ikan dapat memanfaatkan pakan yang diberikan secara optimum sehingga pakan tersebut diserap dan diubah menjadi daging. Sesuai dengan pernyataan Stickney (1979) 
bahwa nilai rasio konversi pakan berhubungan erat dengan kualitas pakan, semakin rendah konversi pakan maka makin efisien ikan dalam memanfaatkan pakan yang dikonsumsi untuk pertumbuhan, sehingga bobot tubuh ikan akan meningkat dikerenakan pakan dapat dicerna secara optimum. Sesuai dengan pernyataan Barrows dan Hardy (2001), nilai rasio konversi pakan dipengaruhi oleh beberapa faktor seperti kepadatan, berat setiap individu, umur kelompok hewan, suhu air dan cara pemberian pakan (kualitas, jumlah dan frekunsi pemberian pakan). Besar kecilnya FCR diduga karena penyerapan nutrisi yang berbeda-beda pada setiap spesies, umur dan jumlah ikan uji.

\section{Abnormalitas \\ Berdasarkan hasil uji lanjut} abnormalitas benih berikasarka Patin hasil pemberemelipialsan Artemia yang telah diperkaya menggunakan vitamin A dengan dosis berbeda dapat dilihat pada Tabel 6.

Tabel 6. Hasil Analisis Abnormalitas benih Ikan Patin

\begin{tabular}{lcl}
\hline No & Perlakuan & Abormalitas $(\%)$ \\
\hline 1. & A & $1,00 \pm 2,00^{\mathrm{a}}$ \\
2. & $\mathrm{B}$ & $1,75 \pm 2,36^{\mathrm{a}}$ \\
3. & $\mathrm{C}$ & $2,50 \pm 1,91^{\mathrm{a}}$ \\
4. & $\mathrm{D}$ & $4,50 \pm 3,00^{\mathrm{a}}$ \\
5. & $\mathrm{E}$ & $7,25 \pm 0,95^{\mathrm{a}}$ \\
6. & $\mathrm{~F}$ & $7,50 \pm 3,87^{\mathrm{a}}$ \\
7. & $\mathrm{G}$ & $24,00 \pm 7,78^{\mathrm{b}}$ \\
\hline
\end{tabular}

Keterangan:

Nilai yang diikuti huruf kecil yang sama tidak berbeda nyata berdasarkan uji jarak berganda Tukey pada taraf $95 \%$.

$\begin{array}{lcr}\text { Hasil uji } & \text { statistik } \\ \text { menunjukkan } & \text { bahwa } & \text { pemberian } \\ \text { Artemia } & \text { yang } & \text { diperkaya } \\ \text { menggunakan vitamin A pada benih }\end{array}$

ikan Patin memberikan pengaruh yang berbeda nyata $(p<0,05)$ terhadap abnormalitas benih ikan Patin. Rata-rata abnormalitas berkisar antara 1,00\% - 24,00\%. Hal ini diduga karena semakin tinggi dosis vitamin A yang diberikan kepada ikan akan memperlambat pertumbuhan ikan, dan dapat dilihat dalam bentuk fisik dari kelainan bentuk kepala dan tubuh yang tidak normal. Sesuai dengan pernyataan Halver (1985) hanya sedikit vitamin A yang dibutuhkan oleh tubuh larva ikan Gabus dan bila berlebihan akan memberikan efek yang tidak baik terhadap jaringan dan tubuh ikan. Ikan yang memiliki pertumbuhan abnormalitas ditandai dengan ciri-ciri tubuh berwarnah hitam pekat, berenang tidak normal, pertumbuhan lambat, kepala lebih besar dari badan dan suka berdiam di dasar akuarium. Sesuai dengan penelitian Wirawan (2005), abnormalitas merupakan kelainan bentuk kepala, bentuk tubuh dan bentuk ekor. Biedwell et al. (1985) mengemukakan larva ikan yang cacat dapat disebebkan oleh lapisan telur (chorion) yang mengalami pengerasan, sehingga embrio akan sulit untuk keluar. Setelah chorion dapat dipecahkan, maka embrio akan keluar dalam keadaan tubuh cacat.

7. Kualitas Air

Kualitas air merupakan salah

satu penunjang yang dapat mempengaruhi dalam tingkat kelangsungan darhidup laju pertumbuhan organisme perairan yang dibudidayakan (Spote, 1987 dalam Badare, 2001). 
Tabel 7. Pengukuran Kualitas Air

\begin{tabular}{llcc}
\hline No & Parameter & Hasil & $\begin{array}{c}\text { Kisaran } \\
\text { Normal }\end{array}$ \\
\hline 1. & Ph & $6,0-$ & $5,5-8,5$ \\
& & 7,0 & $(\mathrm{SNI}$, \\
2. & Suhu & $27-$ & $2009)$ \\
& & $30^{\circ} \mathrm{C}$ & $27-31$ \\
& & ${ }^{\circ} \mathrm{C}$ \\
& & & $(\mathrm{SNI}$, \\
& & & $2009)$ \\
\hline
\end{tabular}

Bedasarkan hasil pengukuran kualitas air selama penelitian diperoleh rata-rata $\mathrm{pH}$ berkisaran 6,0-7,0. Kisaran ini masi cukup baik bagi kehidupan ikan, bila $\mathrm{pH}$ sudah terlalu asam dan basa bagi ikan dapat menyebabkan kematian dan pertumbuhan terhambat. Sesuai dengan penelitian Syarizal dan Arifin, (2017), menyatakan bahwa ikan kolam air tawar mempunyai titik mati asam pada $\mathrm{pH} \mathrm{4,0} \mathrm{dan} \mathrm{titik}$ mati basa pada $\mathrm{pH}$ 11,0. Sesuai dengan SNI, 2009 rata-rata $\mathrm{pH}$ untuk pertumbuhan ikan Patin ratarata berkisaran 5,5-8,5. Sesuai dengan penelitian Arifin dan Tupang (1983) dalam Nurhamidah (2007), $\mathrm{pH}$ yang cocok untuk kehidupan ikan Patin berikisaran 6,5-8,0.



Gambar 1. Pengukuran Kulitas Air Untuk pengukuran suhu diperoleh rata-rata berkisaran 27-30 ${ }^{\circ} \mathrm{C}$ dan masih berada dalam kisraan toleransi untuk benih ikan Patin, kisaran suhu penelitian cukup baik bagi kehidupan ikan. Berdasarkan (Gambar 1) menyatakan bahwa pertumbuhan pada benih ikan Patin selama penelitian mengalami kenaikan dan suhu dalam batas normal. Jika suhu terlalu tinggi akan berpengaruh terhadap pertumbuhan benih ikan Patin akan melambat. Jika suhu dibawah batas optimum dapat ditoleransi malkan, pakan yang dimakan hanya untuk mempertahankan hidup, tidak untuk tumbuh dan berkembang (Lovell, 1989 dalam Setiawan et al., 2013). Sesuai dengan SNI, 2009 rata-rata suhu untuk pertumbuhan ikan berkisaran 27-31 ${ }^{\circ} \mathrm{C}$. Sesuai dengan penelitian Arifin dan Asyari (1992) dalam Nurhamidah (2007), ikan Patin yang dipelihara dapat tumbuh dengan baik pada kisaran suhu 26,5-28 ${ }^{\circ} \mathrm{C}$. Sesuai dengan penelitian Wihardi et al. 2014, suhu air sangat mempengaruhi laju pertumbuhan, laju metabolisme ikan dan nafsu makan ikan serta kelarutan dalapksagien

\section{KESIMPULAN}

Berdasarkan hasil penelitian yang dilakukan pada benih ikan Patin

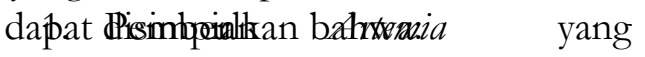
diperkaya vitamin menggunakan A dengan dosis

berbeda memberikan pengaruh tidak berbeda nyata terhadap laju pertumbuhan harian, laju pertumbuhan bobot harian, pertumbuhan bobot mutlak, pertumbuhan panjang, Rasio Koversi Pakan (FCR), tingkat kelangsungan hidup, tetapi berbeda nyata terhadap abnormalitas benih ikan Patin.

2. Dosis pengkayaan Artemia menggunakan vitamin A yang optimum bagi pertumbuhan 
benih ikan Patin adalah tidak lebih dari $100 \mathrm{mg} / \mathrm{L}$.

\section{SARAN}

\begin{tabular}{lr}
\multicolumn{1}{c}{ Perlunya } & dilakukan \\
penelitian pengkayaan & Artemia \\
menggunakan vitamin A & tidak \\
lebih $100 \mathrm{mg} / \mathrm{L}$ menggunakan ikan \\
jenis lainnya.
\end{tabular}

\section{DAFTAR PUSTAKA}

Afrianto. Eddy. dan Evi L. 2005. Pakan Ikan.

Yogyakarta: Kanisius.

Agus,2M1.0D. RePgatinai daReB̉edarfin

Jenis Pakan Alami daphnia, Jen5tik Nyamuk dan Cacing Sutra Terhadap Pertumbuhan Ikan Cupang Hias. Jurnal PENA Akuatika. Universitas Pekalongan. Pekalongan

Badare, A. I. 2001. Pengaruh Pemberian Makroalgga Terhadap Pertumbuhan dan Kelulusan Hidup Juvenil Abalone (Holiotis spp) yang dipelihara dalam Kurungan Terapung. Program Studi Budidaya Perairan Fakultas Pertanian Undana: Kupang.

Barrow, P. A. dan Hardy. 2001. Probiotic For Chickens. In: Probiotics the Scientific Basis. R. Filter (Ed). London: Chapman and Hall.

Bunasir. Fahmi, M. N. dan Fauzan, G. T. M. 2002. Pembesaran ikan papuyu (Anabas testudineus Bloch) yang dipelihara dalam kolam sebagai salah satu altrenatif usaha (Laporan Perekayasaan). Loka karya Budidaya Air Tawar Kalimantan Selatan. Direktorat Jendral Perikanan. Banjarbaru.

Dedi, J., T. Takuchi., T. Seikai, And T. Watanabe. 1995. Hypervitaminosis and Safe Levels of Vitamin A for Larval
Flounder Paralichthy olivaceus Fed Artemia Nauplii.

Aquaculture, p. 135-146.

Djarijah, S. L. 2001. Pembenihan Patin. Kanisius. Yogyakarta. Effendi, M. I. 1979. Metoda Biologi

Perikanan. Yayasan Dewi Sri.

Bogor. 112 hal.

Effendi, M. I. 1997. Biologi Perikanan. Yayasan Pustaka Nusantara. Yogyakarta. 163 hlm.

Effendie, M. I. 2002. Biologi Perikanan. Yogyakarta: Yayasan Pustaka Nusantara. Ernawati. dan Hamsir. 2019.

Bioenkapsulasi Karotenoid pada skeletonema costatum dan Artemia Terhadap

Pertumbuhan dan Kelangsungan Hidup Larva Ikan Nila Air Tawar. Jurnal Airaha, Vol. VIII. Hal 105-113.

Hafezieh, M. Kamarudin, M.S. Saad, C. R. B. Abd Sattar, M. K. Agh, N. Adn Hosseinpour, H. 2009. Effect of Enriched Artemia Urmiana on Growth, Survival and Composition of Larva Persian Sturgeon. Turkish Journal of Fisheries and Aquatic Sciences.

Hardiman. Isriansyah. dan M. Ma'ruf. 2017. Pengkayaan Artemia sp. Menggunakan Vitamin A Terhadap Kelangsungan Hidup dan Pertumbuhan Larva Ikan Gabus (Channa striata). Jurnal Aquawarman. Vol. 3 No. 1. Hardinata, F. 2009. http//google.com.

Pembenihan Ikan Patin Djambal. Balai Budidaya Air Tawar Jambi. Ds. Sungai Gelam Lecematan Kumpeh Ulu Kebupaten Muaro Jambi. 
Kemenkes RI. 2018. Hasil Utama

RISKESDAS 2018, Jakarta:

Balitbang Kemenkes RI.

Kementerian Kelautan dan

Perikanan. 2011. Stasiun

Karantina Ikan Kelas I Hang

Nadim Batam. Badan

Karantina Ikan, Pengendalian

Mutu dan Keamanan Hasil Perikanan.

Lovell, R. T. 1984. Ascorbic Scid Metabolisme in Fish Proceeding Asobic Acid In

Domestic Animal.

Copenghagen: The Royal

Danish Agricultur Soc. P.

206-212.

Mia. S., Dian. P., Dedi J. 2013.

Sintasan dan Pertumbuhan Larva Ikan Patin yang diberi Artemia Mengandung Vitamin

C. Akualkurthar

Indonesia. 12(2), 136-143. 2013.

National, R. C. 1993. Nutrient Requiremnts of Fish. National Academy Press. Washington. Hlm 22.

Nurhamidah, D. 2007. Pengaruh

Padat Penebaran Pada Benih Ikan Patin dengan Sistem Resiskulasi. Skripsi (Tidak dipublikasukan). Dapertemen Budidaya Perairan, Fakultas Perikanan Ilmu Kelautan, Institut Pertanian Bogor.

Saputra, A. 2010. Pertumbuhan beberapa Strain Ikan Patin (Pangasius) Yang Dipelihara Dalam Tambak Brsalinitas Rendah. Pusat Riset Perikanan Budidaya Jakarta.

Setiawan, M., Darina. P. dan Dedi J. 2013. Sintasan dan Pertumbuhan Ikan Patin yang diberi Artemia menggunakan Vitamin C. Jurnal Akuakultur Indonesia. 136-143 hlm.
SNI. 2009. Ikan Patin Jambal. Badan Standar Nasional/BSN. SNI 7471.2:2009. Jakarta.

Stickney, R.R. 1979. Principles of Warm Water Aquacultur. John Wiley and Sons Inc. New York. Pp 223-229.

Verdegem, M. And E.Edding, 2010. Aquacultur Production System. Lectur Note. Aquacultur and Fisheries Wagenigen University.

Wihardi, Y., Yusanti, I.A dan Haris, R.B.K. 2014. Ferminisasi pada Ikan Mas (Cyprinus carpio) dengan Perendaman Ekstral Daun-Tangkai Buah Terung Cepoka pada Lama Waktu Perendaman Berbeda. Jurnal Ilmu Perikanan dan Budidaya Perairan. 9(1) : 23-28.

Wirawan, I. 2005. Efek Pemaparan

Copper Sulfar (CuSO3) terhadap Daya Tetes Telur, Perubahan Histopatologik Insang dan Abnormalitas Larva Ikan Zebra (Brachydanio rerio). Tesis. Program Pasca Sarjana. Universitas Airlangga. Surabaya. 77 hal.

Yurisman. dan Heltonika, B. 2010. Pengaruh kombinasi pakan terhadap pertumbuhan dan kelangsungan hidup larva ikan selais (Ompok bypophthalmus).Jurnal Berkala Perikanan Terubuk. 38(2):80-94. 